\title{
UNITS OF ACCOUNT IN GOLD AND SILVER IN SEVENTH-CENTURY ENGLAND: SCILLINGAS, SCEATTAS AND PANINGAS
}

\author{
John Hines, FSA \\ John Hines, School of History and Archaeology, Cardiff University, Humanities Building, Colum \\ Drive, Cardiff CFIo 3EU. UK. E-mail: hines@cardiff.ac.uk
}

The seventh-century vernacular laws from the kingdoms of Kent and Wessex specify fines or compensation payments using units of account that have given us familiar terms in the numismatics of this period: scillingas (shillings), sceattas and pæningas (pennies). In light of the use of cognate words in Gothic and Old High German, and the comparative values given in the Old English law-codes themselves and in the fifth-century Theodosian Code, it is suggested that these represent a regular and durable bimetallic system correlating values in gold and silver. This proposition is examined further against the evidence of weighing-sets from sixth- and early seventh-century Anglo-Saxon graves, and it is argued that the results give greater and more precise meaning to the use of gold and silver in Early Anglo-Saxon artefacts, such as the great gold buckle from Mound I at Sutton Hoo, Suffolk.

\section{THE SEVENTH-CENTURY SOURCES}

There are four extant Old English law-codes which purport to be copies of texts composed in the seventh century: three from Kent (the Laws of Æthelberht, $c$ ?570-6I6, Hlothere and Eadric, $c$ 673-85, and Wihtred, 691/2-725) and one from Wessex (the Laws of Ine, 688-728). I The composition of Wihtred's code is dated in its preamble to the fifth 'winter' of his reign: apparently August or September 696. Moreover, the copying of one law between Ine's code and Wihtred's, which looks very much like an insertion at the end of the latter law-code, is commonly taken as evidence of West Saxon influence and probable hegemony in southern England in the late seventh century. A substantial payment was made by Wihtred to Ine in 694 in order to gain recognition of his kingship and to buy peace from the West Saxons because Mul, a distant cousin of Ine's but brother of the then king Ceadwealla, had been slain by the men of Kent in 687. Details of that transaction are discussed further in the course of this paper. The apparent relationship between Ine's and Wihtred's law-codes thus also dates the Laws of Ine to early in his reign, as is also implicit in the fact that a Bishop Eorcenwald, presumably the known Bishop of London (675-c 694), was consulted when they were composed.

For the Kentish laws, we depend upon a single manuscript copy of the texts, in the earlier twelfth-century Textus Roffensis (dated II23-4). ${ }^{2}$ Ine's Laws are preserved only

I. Liebermann I903-I6, I, 3-I4, 88-I23; Attenborough 1922, 2-6I.

2. Wormald I999, 244-53. 
appended to the law-code of Alfred the Great (87I-99), the earliest copy of which is in the Parker manuscript (Corpus Christi College, Cambridge, I73) of the earlier tenth century. In the 730s, Bede reported that Æthelberht, the first Christian king amongst the AngloSaxons, had had a law-code written down 'following the models of the Romans' but 'in the speech of the English'. ${ }^{3}$ It is manifest, not least from the orthography employed for the Old English (OE) texts, that the surviving copies are not precise transcriptions of seventhcentury exemplars. None the less, careful evaluation of the vocabulary, style and contexts of these four codes has led all serious scholars to conclude that they are essentially what they claim to be: reliable copies of these earliest English law-codes. ${ }^{4}$

Amongst the peculiarities of terminology within these texts is to be counted a series of units of account in which standard compensation payments or fines are expressed. This is particularly the case with Æthelberht's Laws, the most extensive of the three Kentish codes and the basis for the developments and extensions of later legislation. The code lists due payments for a wide range of forms of personal injury or loss of property in quite a systematic manner, varying according to the social rank of either the victim or the perpetrator. Most of the compensations are counted in units of a scilling, a familiar term that survived in use until very recently as the monetary unit 'shilling'; others are counted in sceattas. ${ }^{5}$ The smaller number of additional finds and status-values specified in Hlothere and Eadric's and Wihtred's codes are all expressed in scillingas, except for Wihtred §9, where the penalty on an unfree man who works on a Sunday is given as eighty sceattas. Ine's law-code also has the scilling besides another term, pening: the ancestor of our word 'penny'.

The systematic pattern of Æthelberht's code reveals that the sceatt counted as a fraction of the scilling, at a rate of twenty sceattas to the scilling. This is illustrated most clearly by the compensations specified for the loss of fingers or toes, where it is explicitly noted that each toe is worth half of the equivalent finger (big toe: thumb, etc), down to the nail of the big toe, which is worth thirty sceattas whereas the thumbnail is worth three scillingas, while any other fingernail is worth one scilling and any other toenail ten sceattas. ${ }^{7}$ There is no obvious reason why Wihtred $\$ 9$ should not have read four scillingas rather than eighty sceattas.

There are knotty problems in determining the relationship between the sceatt of the Kentish laws and the pening of Ine's. The fact that the wergild of the highest rank of nobleman - the eorlcund manne, 'earl-kind man', of Hlothere and Eadric $\S \mathrm{I}$ and the

3. iuxta exempla Romanorum ... conscripta Anglorum sermone. Bede, Historia Ecclesiastica, II, 5, in Colgrave and Mynors 1969.

4. Wormald I999, 93-106; Lendinara 1997; Fell I983. Bede's statement (Historia Ecclesiastica, III, 8) that Eorcenberht of Kent (c 640-64) was the first king to outlaw idol-worship in his kingdom and to prescribe observance of Lent implies the existence of at least one law-code that is now lost.

5. scilling, $\mathrm{pl}$ scillingas; sceatt, $\mathrm{pl}$ sceattas. These are both masculine a-stem (alias 'strong') nouns in Old English (OE).

6. pening is also a masculine a-stem noun (cf note 5). In the three Anglo-Saxon manuscript copies of Ine's Laws the term is variously spelt: usually pening, once peneg, in Textus Roffensis $(\mathrm{H})$, and penig, peneg and peoneg in CCC 383 (B). The word is derived from a West Germanic root *pand (pand = 'token', 'pledge' in Old High German) with the suffix -ing, which caused the sound-change known as $i$-mutation: the form with $e$ in the root syllable is a distinctly early form, which may therefore point to an early exemplar for the CCC I73 (E) text: Campbell I959, §193(d). We cannot date $i$-mutation precisely, but it was a relatively early $\mathrm{OE}$ sound-change, and implies that this word was current in at least some dialects of Old English by the time of Æthelberht's Laws.

7. AEt pām oðrum tāum gehwilcum healf gelde ealswà cet pām fingrum is cwiden: 'For each of the other toes, pay half of what is specified for the fingers'. Æthelberht $\$ \$ 70-I$. 
Table I. Fines expressed in pence in the three Anglo-Saxon manuscript versions of Ine's Laws

\begin{tabular}{|c|c|c|c|c|c|c|}
\hline \multirow[b]{2}{*}{$\S 44$ tax blanket (gafolhwitel) } & \multicolumn{2}{|c|}{$\mathrm{CCC}_{173}(\mathrm{E})$} & \multicolumn{2}{|c|}{$\mathrm{CCC}_{383}(\mathrm{~B})$} & \multicolumn{2}{|c|}{$\begin{array}{l}\text { Textus } \\
\text { Roffensis }(\mathrm{H})\end{array}$} \\
\hline & 6 & peninga & 6 & penega & 6 & peninga \\
\hline$\S 58$ an ox's horn & IO & peninga & I4 & penn. & IO & peninga \\
\hline$\S 59$ a cow's horn & 2 & peninga & 2 & peniga & 5 & peninga \\
\hline$\$ 59$ an ox’s tail & I & scill. & 4 & peonega & I & scilling \\
\hline$\$ 59$ a cow's tail & 5 & (pence) & 5 & penega & 5 & peninga \\
\hline$\S 59$ an ox's eye & 5 & $p$ & 5 & peonega & 5 & peninga \\
\hline$\S 59$ a cow's eye & I & scill. & I & scill' & I & scilling \\
\hline$\S 69$ a sheep's fleece & 2 & peningum & 2 & penegum & 2 & penegum \\
\hline
\end{tabular}

cyninges geneat, 'king's companion', of Ine §I9 - is 300 scillingas in Kent and I,200 scillingas in Wessex would be consistent with a shilling of five pence, as is clearly attested much later in Wessex, ${ }^{8}$ assuming equality of sceatt and pening: $300 \times 20=6,000 ; 1,200 \times 5=6,000$. Below this, however, there is no obvious way of reconciling the further wergilds for freemen of 600 and 200 scillingas in Wessex with the I00-scilling 'ordinary' or freeman's wergild of Æthelberht $\$ 2$ I and Hlothere and Eadric \$3, other than by postulating differences in social ranking in the two kingdoms.

Pcningas are the units of account used to express values for a few rather everyday objects such as a blanket and a fleece, and compensation for parts of a disfigured ox or cow, in Ine's Laws ( $\$ \$ 44,58-59$ and 69; see table I). There are textual inconsistencies here between all three principal manuscripts: the ten-paning value placed upon an ox's horn in the CCC I73 and Textus Roffensis copies is fourteen peningas in CCC 383 , and the twopaning value of a cow's horn in the two CCC manuscripts is five paningas in Textus Roffensis. The fact that these particular sums in peningas are interspersed in Ine $\$ \$ 58$ and 59 with values expressed as a scilling is consistent with an exchange rate of four pence to the shilling - which is widely supposed to be the rate of a 'Mercian shilling'. The Leis Willelme, attributed to William the Conqueror but apparently compiled in the reign of Henry I, distinguish fines paid in different units of currency under a Mercian, West Saxon and a Dane Law, which includes equating $L$ souz en Merchenlahe [e] XL souz en Westsexenelahe: '50 shillings under the Mercians' Law and 40 shillings under the West Saxons' Law'. The Leges Henrici of III4-I8 $(\$ 34,3)$ identify the sol. in Westsexa ... ex v. den.: 'shilling in Wessex of 5 pence'. ${ }^{9}$ The fourpenny shilling is first securely attested in Æthelstan's London code of the 930s (VI Æthelstan \$2), and represents a Carolingian definition of a silver solidus as a unit of account of one-sixtieth of a pound of silver that is first attested in the late eighth century. ${ }^{\text {IO }}$ Calculations of sixty shillings to the pound do indeed also appear in a short lawcode known as Mircna laga, 'The Laws of the Mercians', which purports to list the wergilds of Mercian society, but there is room for considerable doubt over the antiquity and authenticity of this code: it exists only in eleventh-century compilations that manifestly seek to plug gaps in the corpus of written law. II In the text of Ine's Laws, MS CCC 383 also replaces the term

8. Grierson and Blackburn 1986, I57; Ælfric, Grammar, §50: Zupitza I880.

9. Liebermann 1903-I6, I, 495, 565.

Io. Ibid, I74-5; 60 solidi of 4 denarii each gives $240 d$ to the pound of silver (pound sterling).

II. Ibid, 462-3; Wormald I999, 39I-3. 
scill [ing] of the other versions with iiii peonega, ' 4 pence': but this is itself an early eleventhcentury copy.

If four paningas to the scilling was the rate when Ine's code was issued, we would be able to make no direct conversions between the units of account in late seventh-century Kent and Wessex respectively. Since we find exactly the same coins across southern England throughout the seventh century, and particularly in the final decades of the century, that would be a very strange state of affairs. According to the West Saxon Parker Chronicle, Ine's recognition of Wihtred's kingship was bought at the cost of paying ccc mil., ' 300,000 ', in compensation for the slaying of Mul. It will be shown below that this is a realistic figure if we assume it to represent the sceatt/pening as a common unit between Kent and Wessex. It is therefore altogether reasonable, though anything but unproblematical, to follow Liebermann in judging the actual figures in Ine $\$ \S 58-59$ to be historically unreliable, and to rely on the one point where a plausible equivalence between the Kentish and West Saxon laws can be found, in the highest wergild, in seeking to solve this problem. In judging these clauses of Ine's Laws in this way we may note the intrinsic illogicality, as the text stands, of valuing an ox's horn and eye above that of a cow, if we assume four peningas to the scilling, but a cow's tail above an ox's on that same rate (see table I). With five paningas to the scilling the distinction between cow's and ox's tails at a scilling and five peningas respectively is a meaningless one, but this is a textual and lexical problem rather than a juridicial one. The text very clearly is imperfect.

\section{COGNATE TERMS IN OTHER EARLY GERMANIC LANGUAGES}

Kent and Wessex in seventh-century southern England were not alone in making use of this terminology: its source and significance may be sought in a broader Germanic context. All three terms were demonstrably known and used in Old High Germanspeaking contexts in the Merovingian and Carolingian lands on the Continent. Even more informative, perhaps, is the fact that skatts and skilliggs, words with the same Germanic roots as $\mathrm{OE}$ sceatt and scilling, appear in the small range of Gothic vernacular texts extant from the fourth to sixth centuries. ${ }^{\mathrm{I} 2}$

The principal surviving Gothic text consists of large fragments of a fourth-century translation of the New Testament (the four Gospels and the Pauline Epistles) by Bishop Ulfilas, along with a small portion of the Book of Nehemiah and a commentary (Skeireins) on John's Gospel. There are, or were, also two vernacular deeds or charters on papyrus from early sixth-century Ostrogothic Italy; conveniently, those contain parallel Latin and Gothic texts. ${ }^{13}$

None of the Gothic sources contains both terms, skatts and skilliggs, whereby one might confirm their semantic relationship to one another. Nevertheless, the sources clearly imply a consistent scheme, under which the two terms refer regularly to distinct types of coin. In the deeds, skilliggs translates Latin solidus, a gold coin at this date, the largest denomination in regular circulation in the Empire from the late third century

I2. The alphabet and orthography used for writing Gothic were adopted from Greek. Consequently the digraph $g g$ is used to represent the nasalized palatal stop [ $\mathrm{y}$ ], conventionally spelt $n g$ in English.

13. Wrede I913. The original of one of the two deeds is lost, but a transcription was made in the I8th century. 
onwards (initially five to the uncia, 'ounce'; for most of its history six to the ounce) and still produced in large quantities in the sixth-century Byzantine Empire. ${ }^{\mathrm{I}}{ }^{\text {skatts, by }}$ contrast, is used to refer to silver currency. In the Gospels, this is the term used regularly as the equivalent of Greek $\alpha \rho \gamma v \dot{\rho} \iota \nu \nu$, a silver coin, and $\delta \eta \nu \alpha \rho \iota \nu$, 'denarius', a specific denomination of silver coin. ${ }^{\text {I5 }} \alpha \rho \gamma v$ ' $\rho \iota \nu \nu$ is occasionally rendered simply with Gothic terms for 'silver', silubrens (adj) or silubr (n), or by the general word for 'money' in Gothic, faihu. ${ }^{16}$ Neither skatts nor skilliggs appears to be a non-specific term for 'coin', only haphazardly used.

The Gothic vocabulary of coinage is, indeed, consistently precise and careful.

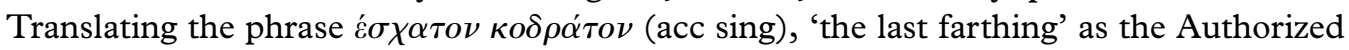
Version puts it, in the gospel of Matthew (5:26), Ulfilas used the term kintus, apparently a loan-word from Latin cententionalis, a demonination in circulation for only a relatively short time in the fourth century; another Latin loan-word is aiz, from aes, a denomination of bronze coin. ${ }^{17}$ Referring to sparrows as 'two a penny', Ulfilas rendered Greek $\alpha \sigma \sigma \alpha \rho$ ' with assarjus, again a term referring specifically to low-value bronze coinage. ${ }^{\text {I8 }}$ Another term adopted directly from the Greek text, for a specific silver coin, is $\delta \rho \alpha \chi \chi \mu \alpha$ as dragma, while in the Book of Nehemiah the Hebrew measure shekel appears as silubris sikle, 'shekels [gen pl] of silver'. ${ }^{19}$ In retelling the parable of the talents, Greek $\mu \nu \alpha$ is rendered with Gothic daila, a noun meaning 'portion' or 'share'. One may confidently infer, therefore, that the key Gothic terms of interest here, skatts and skilliggs, were precisely used in linguistic recognition of distinct monetary units in silver and gold respectively.

Although the circumstances for the survival of evidence should have been more favourable, the internal evidence from Old High German (OHG) is less informative on the systematic use of this terminology than that of Gothic. There are few recorded examples of the term scilling in OHG; however, a glossary, of which several copies are known, dating from the eighth century onwards, translates Latin aureus with scilling and states that there are six of these units to the ounce, confirming the identification of the scilling with the gold solidus as in the Gothic sources. ${ }^{20}$ The aureus was a gold coin in regular production and circulation from the early imperial period of Rome. Diocletian's coinage reforms of $c \mathrm{AD} 295$ sought to standardize the weight of the aureus at one-fifth of an ounce, with sixty to the libra, 'pound'; from this time onwards the term solidus rapidly replaced aureus in official use. During his reign, Constantine reduced the size of the solidus

I4. Mattingly I960, I20-I, 2II-I2; Burnett I987, II4. Harl I996, 473-83, provides a most helpful glossary with definitions of Roman numismatic terminology.

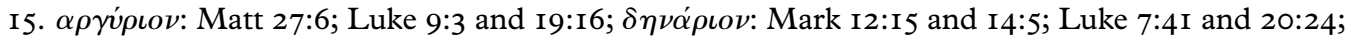
John 6:7 and I2:5; cf Snædal I998, svv SKATTS and SKILLIGGS.

I6. silubrens: Matt 27:3 and 27:9; silubr: Matt 27:5; Luke I9:I5 and I9:23; faihu, Matt I4:II.

17. kintus: see Harl 1996, 476, sv CENTENTIONALIS; Green 1999, 205; ibid, I73 also notes that kintus was subsequently borrowed by Slavonic languages from Gothic. aiz: used in rendering Mark 6:8, $\mu \eta \dot{n} \ldots \chi \alpha \lambda \kappa o ́ \nu$, 'not one brass coin'.

I8. Matt I0:29.

19. dragma: Luke 15:8-9; sikls: Neh 5:15.

20. Stater est nummus, ut quidam affirmant, unciam unam, aureos sex: waga ist silihhono, so sume zufastinot, unce ainam, scillinga sehsi. Latin: 'The stater is a coin, as certain men affirm, one ounce, six aurei/scillingas': Steinmeyer and Sievers I879-98, I, 254-5. The first three words of the OHG gloss do not render stater est nummus, but rather mean 'There is a weight of siliquae ...'. We should also note here a separate gloss on the Book of Isaiah where scillingas is used as a term to explain gold or silver half-moon pendants worn by women: Steinmeyer and Sievers I879-98, I, 589 . 
to the lower weight of one-sixth of an ounce $(c 4.55 \mathrm{~g})$. $^{2 \mathrm{I}}$ The term aureus nevertheless remained in colloquial use, and in sixth-century Gaul was Gregory of Tours' usual term for a gold coin, which we can assume to be the solidus as he also uses the term trians for its smaller fraction, the 'third' or tremissis. ${ }^{22}$ That the terms aureus and solidus are synonymous appears also to be stated in a set of marginal glosses to the Carolingian Capitulare de villis imperialibus of $8 \mathrm{I} 2,{ }^{23}$ except, tantalizingly, for an additional comment that seems to draw a distinction between solidi and aurei that are six to the ounce, or four scripiles ('scruples') in weight, and a solidus aureus vel argenteus of three scripiles. This description is in fact appropriate for a silver denarius of which there were eight to the ounce, as we shall shortly see. Despite such evidence for some rather casual and inconsistent use of the Latin terminology, the evidence does indicate that the Germanic term scilling was used both widely and regularly for the gold solidus from the Late Antique into the Carolingian period on the Continent.

The situation with scaz (the OHG derivative of the root that gives Gothic skatts and OE sceatt) is less clear, however. The same OHG glosses referred to above contain a translation of Latinized denarius as $s c a z$, at least in the earlier, eighth- and ninth-century recensions, albeit with another puzzling addition: pondus est xxiii; eda pfantinc is dri anti zuuainzuc. The former can be translated 'the weight is 23 ' and the latter 'or a penny is twenty-three'. In a tenth-century recension of this gloss, the head-word denarius is simply glossed as pfentinc, 'penny'. ${ }^{24}$ In general, unfortunately, the OHG evidence of the eighth to tenth centuries, which is entirely from lexical and biblical glosses, does not point to any stable identification of the scaz with a particular coin or unit of value. It appears, for instance, as the equivalent of minutum and obolus, 'a small coin' - the latter identified as worth just one-sixth of a silver denarius in the marginal glosses to the Capitulare de villis imperialibus - and of assis and aes, which are bronze coins. The glossary definition of dragma, 'drachma', est scriptulos iii/ist ander halp scaz - 'this is 3 scruples'/'this is one and a half scaz' - implies that the scaz has a weight-value of two scruples. ${ }^{25}$ The Carolingian scrupulus should be a twenty-fourth of an ounce or $1.137 \mathrm{~g}$, which would give us a scaz weight of $2.274 \mathrm{~g} .{ }^{26}$ Congruent with the three-scruple weight given for the dragma in the glossary tradition is the marginal gloss on fol 16 of the Capitulare de villis imperialibus: Dragma denarium significat. viii denarii, id est dragm., efficiunt unciam. vi oboli faciunt dragma: 'Dragma means denarius. 8 denarii, or dragmae, make an ounce. 6 oboli make a dragma'. We can conclude that, when used as a unit of value, OHG scaz usually refers to a coin of less precious metal and lower value than the gold solidus/scilling, but we cannot be more precise than that.

2I. See note IO, above, and Burnett I987, I26-7. We cannot give a weight for the standard Roman libra, 'pound', and uncia, 'ounce', with absolute precision (see Spratling 1980). The reference values adopted here are 327.45 g to the pound and so (to two decimal places) $27.29 \mathrm{~g}$ to the ounce. It is important to note that, by the Carolingian period, the concurrent use of different pound-weights is explicitly accepted in official documentation.

22. Gregory of Tours, Libri historiarum: Krusch and Levison I95I. Levison's valuable 'Index Lexica et Grammatica' (ibid, 567-64I) allows one to locate and compare all the uses of these terms in Gregory's text. Both aureus and solidus are used, in some cases clearly for the same coin; solidus is the less frequent choice and is much more likely to occur where Gregory is quoting some character's words.

23. Borethus I883-90, I, 82-9I; II, 537-8.

24. Steinmeyer and Sievers I879-98, I, II2-I3.

25. Ibid, II4-I5.

26. Witthöft I984, 37 and $4 \mathrm{I}$. 


\section{BIMETALLISM IN SEVENTH-CENTURY ENGLAND?}

There is a case to be made that the pairings of both sceattas and peningas with scillingas in the seventh-century Anglo-Saxon law-codes also represents a regular method of correlating and converting units of account in silver and gold respectively. In this case, however, the system is easiest to explicate if the English scilling is not to be equated with the Roman solidus but rather with the smaller Roman and post-Roman gold coin occasionally noticed by Gregory of Tours as the trians: the tremissis, one-third of the size of the solidus. This identification of the scilling was, indeed, proposed by the numismatist Philip Grierson in I96I and has become quite widely accepted, albeit without particularly strong corroborative evidence. ${ }^{27}$ Grierson's argument was based fundamentally on the fact that the tremissis was the only gold coin familiar in seventh-century England. He supported his proposition by suggesting that the introduction of a light tremissis of $\mathrm{I} .3 \mathrm{~g}-$ and consequently a light solidus of $3.9 \mathrm{~g}$, of which there were therefore seven rather than six to the ounce ${ }^{28}$ - was founded upon the adoption of the Troy (barley) grain as a base weightmodule of $0.065 \mathrm{~g}$. This tiny quantity of gold he then identified with the sceatt, twenty of which make a scilling in the Kentish law-codes: $0.065 \times 20=\mathrm{I} .3$.

There is, however, an alternative explanation. In considering the nature of the sceatt of the Kentish law-codes, it has also been noted that the counting of sceattas in groups of ten or twenty could also make good sense if we posit that the sceatt is one-twentieth of the Roman ounce: $1.365 \mathrm{~g}$ if we take a standard Roman ounce as $27.29 \mathrm{~g} .{ }^{29}$ This in fact a little higher than the mean coin-weight of the earliest silver coins of late seventh-century England. ${ }^{30}$ Moreover, virtually no silver coinage was being produced in western Europe after the later fifth century, and for a period of at least two centuries to the late seventh century the coinage known over most of Iberia, Gaul and England was predominantly gold. ${ }^{3 \mathrm{I}}$

Nevertheless, what would appear a much more practical explanation of the relationship between sceattas and scillingas is provided by the regulation of values promulgated in Roman legislation of the fifth century collected in the Theodosian Code of the 430s. As already noted, by 325 the Emperor Constantine defined the solidus as one-sixth of an ounce of gold. The main surviving text of the Theodosian Code, a Tours manuscript of the late seventh or early eighth century, in fact stipulates a rate of seven solidi to the ounce in this particular ordinance, although it concurrently, and inconsistently, retains the rate of four scruples to the solidus appropriate to one-sixth of the ounce, ${ }^{32}$ and other decrees of 367 and 395 respectively confirm the rate of seventy-two solidi to the pound. ${ }^{33}$ The apparent modification to the text of the law of 325 can be explained in terms of the

27. Grierson I96I; Grierson and Blackburn 1986, I57; Metcalf I993, 29.

28. Nau I97I, 39-40; Witthöft I984, 3I.

29. Lyon I976; cf note 21 , above.

30. Grierson and Blackburn I986, I68.

3I. Grierson I991, 4-28.

32. Si qui solidos appendere voluerit, auri cocti septem solidos quaternorum scripulorum nostris vultibus figuratos adpendat pro singulis unciis, xiiii vero pro duabus. 'If anyone wish to weigh solidi, he should weigh seven solidi of four scruples marked with our face for single ounces, I4 of course for two'. Codex Theodosianus (Mommsen and Meyer 1954), §12.7.I.

33. in septuaginta duos solidos libra feratur: 'a pound should make seventy-two solidi': ibid, §I2.6.3; in una libra auri solidi septuaginta duo obryziaci: 'for one pound of gold seventy-two coined solidi': ibid, \$7.24.I. 
Table 2. The distribution of fines expressed in scillingas in the Laws of Æthelberht. Multiples of 3 emphasized

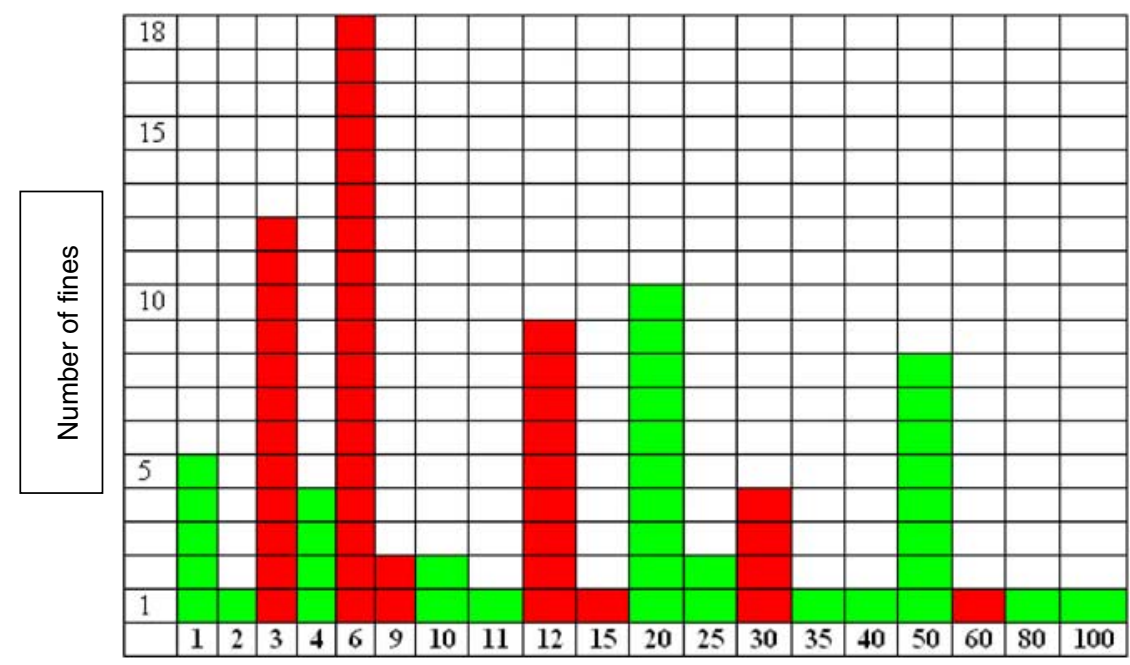

Number of scillingas

Frankish introduction of the light solidus of $3.9 \mathrm{~g}$, one-seventh of an ounce, during the sixth century. ${ }^{34}$

These Roman/Byzantine laws also include fixed exchange rates between gold and silver. In the year 397 a rate of five solidi to the pound of silver was specified; ${ }^{35}$ this meant that a quantity of gold was worth I4.4 times the same amount of silver. In June 422, however, the exchange-rate was revised to four solidi to the pound of silver. ${ }^{36}$ Gold had become more valuable relative to silver, with the exchange rate now I8:I. With six solidi to the ounce of gold, the tremissis is one-eighteenth of an ounce ( $c \mathrm{I} .5 \mathrm{I}-\mathrm{I} .52 \mathrm{~g}$ ). At an exchange rate of $\mathrm{I}$ 8:I, consequently, the tremissis is equal in value to one ounce of silver; this in turn will accord perfectly with the sceatt being one-twentieth of an ounce of silver, while the scilling is the gold tremissis, one-eighteenth of an ounce of gold. Since there was no silver coinage in the time of Ethelberht, this would also mean that the units of account in these two precious metals must have been conceived of essentially as weights of bullion. When the standard solidus is oneseventh of an ounce and there are twenty-one tremisses to the ounce, at the same exchangerate of I8:I the relevant silver weight of the postulated standard sceatt is I.I9-I.20g - which is encouragingly consistent with the actual weights of the earliest silver coins.

Identifying the scilling with the tremissis also clarifies another notable feature of the system of fines in Æthelberht's code. A majority of these fines are in multiples of three scillingas, specially the smaller fines of 3, 6, 9, I2 and I5 scillingas (table 2). Apart from a

34. See note 27 , above.

35. pro singulis libris argenti quinos solidos inferat: 'for single pounds of silver five solidi should be given': Mommsen and Meyer I954, §13.I2.I.

36. Pro singulis libris argenti ... quaterni solidi praebentur: 'for single pounds of silver ... four solidi are to be provided': ibid, $\$ 8.4 .27$. 
few fines of I, 2 and 4 scillingas, and one odd one of I s scillingas, the remainder follow a decimal pattern of multiples of ten (to which scheme we may also assign two at 25 scillingas). The multiples of three are of course nicely explicable as reflexes of compensation payments originally counted in solidi: multiples of three tremisses.

The postulate that the system of units of account is, then, one co-ordinating bullion weights in silver and gold may also make good sense of the principal difference apparent in Ine's late seventh-century West Saxon law-code. However many pennies make a shilling here, either the paning must be worth several times the value of the Kentish sceatt, or the scilling has been devalued. The figures given as a nobleman's wergild obviously imply the latter. A 300,000-sceatt/paning compensation payment for the death of Mul cannot properly be described as a regular wergild: our sources imply there was no such thing for a king or prince (cyning or cepeling) at this date. The historically questionable text of Mircna laga does stipulate a king's wergild of 120 pounds of silver, at a rate then six times a nobleman's wergild (here called a pegn), which is separately given as I,200 scillingas as in Ine's Laws. Mircna laga actually also quotes the figure of 300,000 sceattas as the value of the king's wergild, but no practical sense can be made of a sceatt of which there were then 2,500 to the pound, and 4I.66 to the scilling of one-sixtieth of a pound. ${ }^{37}$ On the rates of the Laws of Ethelberht, however, 300,000 sceattas will be 15,000 scillingas, the same as 5,000 solidi in the rates proposed here. Comparison with the compensation payments noted by Gregory of Tours in sixth-century France suggests this is, in broad terms at least, a realistic sum. ${ }^{38}$

In the course of the seventh century the gold quality of the tremissis was indeed reduced, and the final issues were 'pale gold', some comprising as little as 15 per cent gold alloyed with 85 per cent silver (which itself would include a certain admixture of copper). A rate of five peningas to the scilling would in fact be consistent with a scilling containing just over 20 per cent gold and just under 80 per cent silver. A rate of only four paningas to the scilling is likewise appropriate with a pale gold tremissis of only I5 per cent gold and 85 per cent silver. Empirically, there is no evidence for either 20 per cent or 15 per cent gold becoming standard qualities for late seventh-century pale gold tremisses; we must also note that silver coins themselves became increasingly debased with copper. Nevertheless, the exchange rate that had developed by the time of Ine's Laws is clearly consistent with an attempt to express values in terms of a realistic gold coin standard along with a fixed relative value between silver and gold. The reduction in the gold content of the later seventh-century tremisses was indeed recognized and endorsed as an explanation by Grierson in his article of I96I, but he remained determined to reject any close relationship between the Kentish sceatt and the silver pening because of his conviction that the sceatt was to be equated with the Troy grain.

\section{WEIGHT-SYSTEMS IN EARLY ANGLO-SAXON ENGLAND AND AMONG HER NEIGHBOURS}

The suggestion that precious metals were valued by quantity essentially in units of weight, so that coins were consequently little more than special ingots of more or less predictable

37. As a fraction of a classic Roman pound of $327.45 \mathrm{~g}$, this gives $0.13 \mathrm{Ig}$, which is 2 Troy grains.

38. The most pertinent comparandum would appear to be the compensation and peace-offering of Io,००० solidi paid by Recared, King of the Visigoths in Spain, to Childeberht II for the death of his sister Ingund and implicitly also of her husband: Krusch and Levison I95I, IX, I6. In a different league is the 50,000 solidi paid for the death of Amalasuntha, daughter of Theoderic the Great and niece of Clovis: ibid, III, 3I. 
weight, is not an unfamiliar nor a surprising one. Gregory of Tours refers anecdotally to the estimation of the number of coins in a bag by weight, although the majority of his many references to payments being made in aurei (occasionally he uses the term solidi) or triantes simply refer to coins counted by number. ${ }^{39}$

What is potentially an important parallel to the gold/silver bimetallic value system proposed above for seventh-century England might be found in contemporary Scandinavia. It has long been recognized that an ancient unit of account there, in Old Norse the eyrir ( $\mathrm{pl}$ aurar), is lexically the Latin term aureus borrowed into the language. ${ }^{40}$ Anton Brøgger's careful study of the metrics of the plentiful Norwegian gold hoards of the Migration Period led him to conclude that this unit had been adopted in Scandinavia as early as the fifth or sixth century: its weight, however, is in the range of $26.3-26.8 \mathrm{~g}$, much closer to the Roman ounce. ${ }^{4 \mathrm{I}}$ As in England, an attractive explanation of this association of name with weight is that the eyrir represents the amount of silver equal in value to a known gold coin, the tremissis. It must be emphasized, however, as noted above, that our Late Antique continental sources quite consistently equate the aureus with the solidus rather than with the tremissis, while Byzantine solidi indeed were virtually the only gold coins found in fifth- and sixth-century Scandinavia. ${ }^{42}$

Where a bullion-weight currency has become well established and developed, we might expect to find clear material reflexes in the form of a regular use of hacksilver and hackgold for transactions. There is some such evidence in the relevant areas, but it is certainly not extensive or common. A small group of silver hoards containing considerable amounts of chopped-up silver artefacts is known from fifth-century Denmark, while systematic and directed metal-detecting around early rich 'central places' or 'productive sites', such as Gudme on Fyn, adds more of this material, both silver and gold. ${ }^{43}$ The well-known 'blanks' or coin-shaped ingots in the Sutton Hoo Mound I ship-burial, apparently making the coin hoard up to forty tremisses/scillingas, can be counted in the same light. ${ }^{44}$ Gold and silver would, of course, have been carefully looked after and so less subject to casual loss. Nevertheless, a comparison of the coin evidence we have from the fifth to seventh centuries in England with that for collections of small pieces of gold and silver bullion argues firmly against a widespread and large-scale use of hacksilver and hackgold currency in this period.

Direct evidence of the practice of weighing small quantities of material in these communities is, however, provided by finds of weighing equipment: balances with scale-pans and weights, together sometimes with touchstones for testing the fineness of precious metals. There are several examples from England and the Continent; some, but fewer, from Scandinavia. ${ }^{45}$ Our concern here is primarily with the Anglo-Saxon specimens, which were

39. See note 22, above. Ostendebat enim nobis ante die tertia rex duo volucra, species et diversis ornamentis referta, quae praeciebantur amplius quam tria milia solidorum; sed et saccolum cum nummismati auri pondere, tendentem quasi duo milia. 'Before the third day the king showed us two purses, beautiful and decked with diverse ornaments, which were worth more than three thousand solidi; but also a bag contained gold coins, by weight holding the equivalent of two thousand.' Krusch and Levison I95I, V, I8.

40. Brøgger I92I; Kilger 2008, 279-82.

4I. Cf Kilger 2008, 293, for the suggestion that this unit represents a lighter Merovingian ounce. Bakka (I978 and I98I) finds an eyrir module close to the classic Roman ounce, however.

42. Fagerlie 1967; Kyhlberg 1986; Kilger 2008, 284.

43. Voss 1954; Vang Petersen 1994; Jørgensen I994; Jørgensen and Vang Petersen 1998, 200-6I.

44. Kent et al 1976, esp 578-647; Spratling 1980. See further below.

45. Scull 1990; Steuer 1987; Bakka 1978 and 1981; Kilger 2008, 283-4. 
Table 3. Multiples of the lighter weight-module (I.30-I.33g) in the six principal weight-sets (after Scull 1990)

\begin{tabular}{|c|c|c|}
\hline Grave & Module (g) & Weight-multiples \\
\hline Barton-on-Humber & I.30 & I0, 9?, 6?, 2, I $\frac{1}{2}, \frac{1}{2}$ \\
\hline Buckland, Dover C & I.32 & $\mathrm{I} 6, \mathrm{I} 4,3,2,2$ \\
\hline Gilton 66 & I.33 & 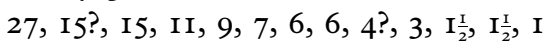 \\
\hline Ozengell & I. 32 & $\mathrm{I} 9, \mathrm{I} 2,7,5, \mathrm{I} \frac{\mathrm{I}}{2}, \mathrm{I}, \mathrm{I}$ \\
\hline Sarre 26 & 1.32 & $48 ?, \mathrm{I} 5, \mathrm{I} 2,7,2, \mathrm{I} \frac{\mathrm{I}}{2}$, I, I \\
\hline Watchfield F.67 & I. 30 & $\mathrm{I} 4, \mathrm{I} 2,5,3,3$ ?, I \\
\hline
\end{tabular}

Table 4. Multiples of the heavier weight-module (I.5I-I.58g) in the six principal weight-sets (after Scull 1990)

\begin{tabular}{|c|c|c|}
\hline Grave & Module (g) & Weight-multiples \\
\hline Barton-on-Humber & I. 52 & $8,4 ?$ \\
\hline Buckland, Dover C & I. 52 & I4, I2?, 8, 6, 6?, 2?, 2, 2 \\
\hline Gilton 66 & I.5I & $40,9,8,2,2$ \\
\hline Ozengell & I. 57 & I6, I4, I2, IO, 6, 6, I, I, $\frac{\mathrm{I}}{2}$ \\
\hline Sarre 26 & I. 58 & 40 ?, I4, I2?, IO?, $8,6,4,4,2$ ?, $2, \frac{1}{2}, \frac{1}{3}, \frac{1}{3}$ \\
\hline Watchfield F.67 & I.53 & $\mathrm{I} 2, \mathrm{IO}, 9,2 ?, 2, \mathrm{I}, \mathrm{I}$ \\
\hline
\end{tabular}

comprehensively reviewed by Scull in connexion with a new find in a burial at Watchfield, Oxfordshire, in the I980s. ${ }^{46}$ Scull had six Anglo-Saxon graves of the sixth to early seventh centuries that contained sets of balances, scales and weights that could support a detailed investigation and attempts to reconstruct the operative weight-system. These include both male and female graves, although the full sets of equipment are known only from male graves; the status of the individuals buried, as indicated by the quantity and range of other grave goods, is moderately high but not exceptional. ${ }^{47}$

The most remarkable of Scull's findings was that the weights included in these weighing sets were adapted to a bimodular weight-system rather than being simple, regular multiples of some single common unit, such as we are familiar with. There is a lighter weight-module of I.32-I.33g (falling to I.30g in the Barton-on-Humber and Watchfield weight-sets), represented in multiples of $\mathrm{I}$ to 48 , with one weight in the Barton-on-Humber set, at $0.65 \mathrm{~g}$, identified as a $\frac{1}{2}$ unit (table 3 ). The heavier weightmodule is $\mathrm{I} .5 \mathrm{I}-\mathrm{I} .52 \mathrm{~g}$ in four sets and $\mathrm{I} .57-\mathrm{I} .58 \mathrm{~g}$ in the other two. This is represented by weights that are multiples of I to 40 units, with two at $\frac{1}{2}$ and two at $\frac{1}{3}$ (table 4 ). The inconsistency in the heavier modules is puzzling. It might, of course, merely represent a range of tolerable error around a mean of $c \mathrm{I} .54 \mathrm{~g}$ (which is pretty much precisely oneeighteenth of a classic Roman ounce), but the variance of 2.08-2.73 per cent in the case of the higher modules is surprisingly high, especially when in multiples of 40 the resultant

46. Scull I986 and I990. It has not been possible here to incorporate details of a more recent find from further excavations at Buckland, Dover, Kent, grave 265.

47. Scull I990, 205-8. 
Table 5. Values of 3, 4, 5 and 6 siliquae and the distribution of the lightest weights in the Anglo-Saxon weight-sets in relation to them

\begin{tabular}{ll}
\hline Value & Approximate weights \\
\hline 3 siliquae $(0.57 \mathrm{~g})$ & 4 in the range $0.53-0.56 \mathrm{~g}$ \\
4 siliquae $(0.76 \mathrm{~g})$ & 7 in the range $0.70-0.8 \mathrm{Ig}$ \\
5 siliquae $(0.95 \mathrm{~g})$ & $\mathrm{I}$ at $0.98 \mathrm{~g}$ \\
6 siliquae $(\mathrm{I} . \mathrm{I} 4 \mathrm{~g})$ & 4 in the range $\mathrm{I.I}-\mathrm{I}-\mathrm{I} .2 \mathrm{Ig}$ \\
\hline
\end{tabular}

difference in actual weight from the putative norm could be as great as $1.6 \mathrm{~g}$, and that between the heaviest and lightest variants $2.4 \mathrm{~g}$. Moreover, there is no set that actually represents any such hypothetical mean as the standard.

In light of Grierson's Troy-grain hypothesis, it should be noted that the lightest weight in the Barton-on-Humber set would be consistent with a desire to be able to weigh out ten grains of gold $(0.65 \mathrm{~g})$. Looking at the sets together, however (table 5), clusters in the distribution of the lightest weights suggests rather a wish to be able to measure in terms of siliquae, the Classical grain weight of the $\kappa \varepsilon \rho \alpha \dot{\tau} \tau \iota \nu$ or carat, nominally $0.19 \mathrm{~g} .{ }^{48}$ The greatest discrepancy would be one of $0.07 \mathrm{~g}$ if the weight of I.2 Ig in the Ozengell set were meant to represent six siliquae. In this set, however, that is paired with a weight of exactly I.I4g. The $0.65 \mathrm{~g}$ weight from Barton-on-Humber is the only one that could not be interpreted in these terms, and this set is the least typical, and appears to be the most imperfectly preserved, of all these weight-sets. It is striking that, despite being better preserved, none of the other sets has any weight that Scull would assign to the lighter series below I.23-I.37g.

In his interpretation of the Watchfield set, Scull indeed interpreted the bimodular system as one designed to check the weights of gold coinage issued to two different weight-standards: the Byzantine tremissis of eight siliquae ( $c$ I.52g) and the Frankish/ western light tremissis of seven siliquae ( $c$ I.33g). ${ }^{49}$ One weight in the Watchfield set and two in Gilton grave 66 are in fact marked with figures representing those units. It is difficult to think why, on this basis, the Ozengell and Sarre sets should be as much as $0.05-0.06 \mathrm{~g}$, some 3 per cent on average, overweight in the heavier series, but that enigma must simply be shelved for now. The provision of equipment suitable for weighing both Byzantine and Frankish tremisses would indeed be more appropriate in sixth-century southern England than for much of the seventh century, and, with the exception of the Barton-on-Humber grave, this is the probable date of all the grave-assemblages Scull was able to analyse in detail.

These bimodular weight-sets are not directly adapted to comparing quantities of silver counted in units of one-twentieth of an ounce and gold in eighteenths or sixths of an ounce, as one would look for in support of the hypothesis of a bimetallic value-system which, in effect, supported a limited currency. Even if we take the mean lower value of $c$ I.52g as a tremissis/scilling standard, the corresponding ounce would be $27.36 \mathrm{~g}$ and the sceatt, therefore, I.37g, which is not consistent with the empirical evidence. This does not, however, mean that the weighing equipment was unsuited to a bimetallic system. Inevitably, the finest

48. Note also Scull's observation that a weight difference of $c 0.2 \mathrm{~g}$ seems to be the smallest that could be estimated with accuracy using this weighing equipment: Scull I990, I88.

49. Scull I986, I20-3. 
weighing must be done of the most precious material, gold. All of the weight-sets would allow the user to weigh ounces and half-ounces of silver accurately (putatively, twenty and ten sceattas), which could then easily be subdivided into quarter-ounces (five sceattas; or, indeed, the five paningas of the inferred later seventh-century West Saxon scilling). All of the lighter module sets would allow twenty units to be added to a gold coin in one scale-pan in order for an equal weight of silver to be placed in the other. The intervals at which weights are provided in each set look irregular, but they allow a wide range of quanta to be measured. It is none the less perfectly clear that they are better suited to examining thirds, sixths and ninths of an ounce than the halves, quarters and tenths of a vigesimal system.

The as-yet unresolved question at the heart of attempts to understand the units of account of seventh-century England might be characterized as the hunting of the sceatt. We know that it existed; we have a good idea of what it was worth; but we cannot conclusively show what it was. There is no more direct empirical confirmation from this early period of a silver sceatt of one-twentieth of an ounce than there is of a gold sceatt of $0.065 \mathrm{~g}$. It can be argued, none the less, that a bimetallic system co-ordinating values in gold and silver is a plausible explanation of the units of account scillingas, sceattas and peningas in the seventh-century Anglo-Saxon sources, and, at the very least, merits equal consideration with the Troy grain hypothesis in future. The bimetallic hypothesis has the advantage of allowing for straightforward co-ordination of the systems between Kent and Wessex, at the same time as rendering those systems consistent with the evidence for longstanding practices of using both silver and gold on the Continent. It is remarkable, but not incredible, that this also implies that Kent thus adhered to a legal decision of the early 420 , enshrined in the Theodosian Code, fixing the exchange rate between gold and silver in the Roman Empire at I:I8. Both coin finds and the weighing sets just reviewed show that both Byzantine 'heavy' and Frankish 'light' solidi and tremisses could appear in Kent and along the Thames from as early as the first half of the sixth century, although finds are considerably more numerous in the south-eastern corner from Hampshire and Sussex to East Anglia than around the Upper Thames. ${ }^{50}$ The weighing sets were primarily adapted to measuring small quantities of gold, but were none the less capable of measuring larger comparable quantities of silver.

The key to understanding the logic of this system may be to recognize that a standard proportionate rate of exchange is of as much - probably more - practical significance than a standard basic weight unit (grain, scruple or ounce) in terms of multiples or fractions of which anything could be measured. In this light, however, the proposed bimetallic system is not intrinsically incompatible with Grierson's grain hypothesis. We can take it that the accurate measurement of a single grain at $0.065 \mathrm{~g}$ was utterly impractical, if not impossible at this date - let alone distinguishing Troy (barley) grains at $0.065 \mathrm{~g}$ from Paris (wheat) grains at 0.059g. There are much later medieval sources that stipulate how 'average' grains should be selected..$^{51}$ In multiples of, say, Io or 20 , however, not only is the variation in size of individual grains around the normal mean compensated for but the total mass comes within the range of practical measurement for comparative weighing. If twenty grains were used to check or even to define the weight of a scilling of gold of I.3g, the comparative rate would be solely a matter of mass, not of values for exchange, but in principle the bimetallic system is thus extensible to correlate other materials and commodities.

50. Rigold 1976; Abdy and Williams 2006; Williams 2006.

51. Kilger 2008, $265 \mathrm{n} 3$. 


\section{GOLD AND SILVER IN EARLY ANGLO-SAXON ARCHAEOLOGY}

Compared with the Continent and Scandinavia in the fifth to seventh centuries, gold and silver were not plentiful in Early Anglo-Saxon England..$^{52}$ The situation varies, inevitably, from region to region and from phase to phase: more silver appears in jewellery and adornments in sixth-century Kent than any other part of England at that date, and in a period of around half a century around the middle of the seventh century the use and burial of gold in female jewellery - such as the famous Desborough necklace - suddenly becomes quite regular, if never profuse, across much of England. ${ }^{53}$ On the question of the exact and relative quantities of silver and gold, there is a further awkward problem in that these precious metals are usually incorporated in composite objects - particularly with inlays of garnet, glass or niello. All the same, it would be worth paying more attention to the precise quantification of the various well-preserved metals - copper alloys, silver and gold - in future reports and studies of Early Anglo-Saxon finds and assemblages.

In a paper from a conference on Anglo-Saxon cemeteries held in 1979, Mansel Spratling argued for extremely close control of weights in the fine metalwork of the Sutton Hoo Mound I deposit, especially the dress-accessories. ${ }^{54}$ Interestingly, here he included items with quite varied levels of incrustation with garnets and millefiore and the like, implying, perhaps, although he did not discuss this, that these materials might be counted with the gold bulk of the items on the same basis as alloyed metals such as silver. Most of the Sutton Hoo Mound I goldwork has a fineness of between 80 and 90 per cent. ${ }^{55}$ Writing before Scull's investigations of weight-sets, Spratling observed that the combination of the thirty-seven Merovingian tremisses with the three blanks of very similar weight would provide coins or tokens with a mean weight of $1.273 \mathrm{~g}$ for each of the forty putative oarsmen, but that inclusion of the two gold 'billets', together weighing I0.I8Ig, would raise the collective payment to a crew of forty to $1.5275 \mathrm{~g}$ per man: very close to eight siliquae, the value of the 'heavy' tremissis.

What one may now identify as the most significant item in this respect in the entire Mound I artefact-assemblage, however, is the familiar great gold buckle (fig I): the largest gold artefact, and indeed an item that is almost entirely gold (of the fineness noted above). It has a little inlaid niello on the face. Analysis reveals that slightly varying alloys of gold were used in different parts of this artefact. It has also been suggested that the fastening mechanism inside the hollow buckle, which has a hinged underside, may have been secondarily reinforced with a set of gold bars, which would of course add to the original weight of the object. ${ }^{56}$ What Rupert Bruce-Mitford suggested to be reinforcement bars (fig $2 \mathrm{~A}$ ), however, are not only extremely slender, merely $0.9 \mathrm{~mm}$ square in cross-section, but are also inappropriately positioned to give the sockets for the closing mechanism any significant support in the way Bruce-Mitford postulated. An internal bar added to support the hinge in the buckle (fig $2 \mathrm{~B}$ ), on the other hand, seems much more likely to be a later addition. The gold fineness of this bar is notably lower than any other

52. Webster 2000.

53. Leeds 1936, 99-100 and I05-IO. It is surprising that more attention has not been paid to this aspect of the consumption of valuable resources: cf Boddington 1990; Geake 1997, esp 126-7.

54. Spratling 1980.

55. The full range is from 70 per cent to 97 per cent, but more than half the objects analysed are in this median range: Hughes et al 1978.

56. Bruce-Mitford 1978, 536-64, esp 539-43. 


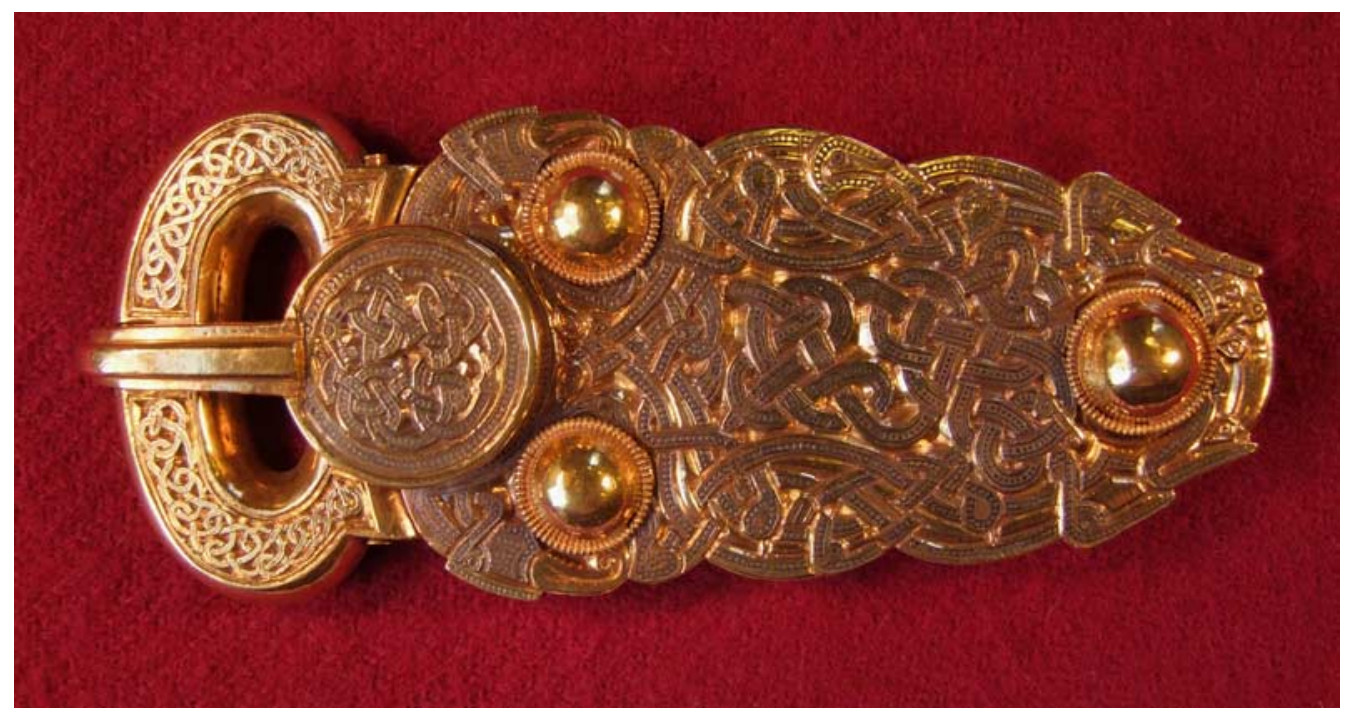

Fig I. Sutton Hoo, Suffolk, Mound I. The great gold buckle - the quantity in gold of a nobleman's wergild? Scale I:I. Photograph: author, courtesy of the Trustees of the British Museum

part of the buckle (77.7 per cent $\mathrm{Au}$; I5.2 per cent $\mathrm{Ag}$; 3.25 per cent $\mathrm{Cu}$ ), ${ }^{57}$ and its edges, exceptionally, are not neatly squared off.

The published weight of this buckle in its present state is $4 \mathrm{I} 2.7 \mathrm{~g}$. Allowing for its irregular ends, the support bar for the hinge is $c 56 \mathrm{~mm}$ long altogether, and $6.7 \times \mathrm{I} .5 \mathrm{~mm}$ in cross-section, giving a total volume of $0.5628 \mathrm{~cm}^{3}$. From its alloy composition, as quoted above, we should expect it to have a relative density of $16.6068 \mathrm{~g}$ per cubic centimetre, and so to weigh nearly $9.35 \mathrm{~g}$ at normal temperature and pressure. That would reduce the weight of the original buckle to $403.35 \mathrm{~g}$. What is especially interesting about this is that it means that the amount of gold in the buckle is very close to the 300 gold scillingas of the Kentish nobleman's wergild (which we postulate was equal to that of the West Saxon nobleman), and that the object certainly contained at least that amount if the scilling is to be equated with the light western tremissis. If the mean weight of the coins and blanks is taken as the reference weight, 300 such units make $38 \mathrm{r} .9 \mathrm{~g}$ and the buckle in its putative original state represents $3 \mathrm{I} 7$ units. If $\mathrm{I} .3 \mathrm{~g}$ is the root, 300 units is $390 \mathrm{~g}$. A threehundredth part of the original weight of the buckle as calculated here is $1.345 \mathrm{~g}$.

It is far from unreasonable to assume that, when it was on display, however that was done, it would not be difficult for at least some men around its possessor to recognize by eye the approximate amount of gold this buckle contained. It would presumably have been practical for its maker to weigh the separate gold components, and to determine the equivalent quantities of wax for the cast components, in order to achieve the desired weight. If the great gold buckle is correctly interpreted in these terms, it must surely be the clinching evidence in the argument for the kingship of the man who was probably buried - at the very least commemorated - in this barrow. It would be in a king's interest 


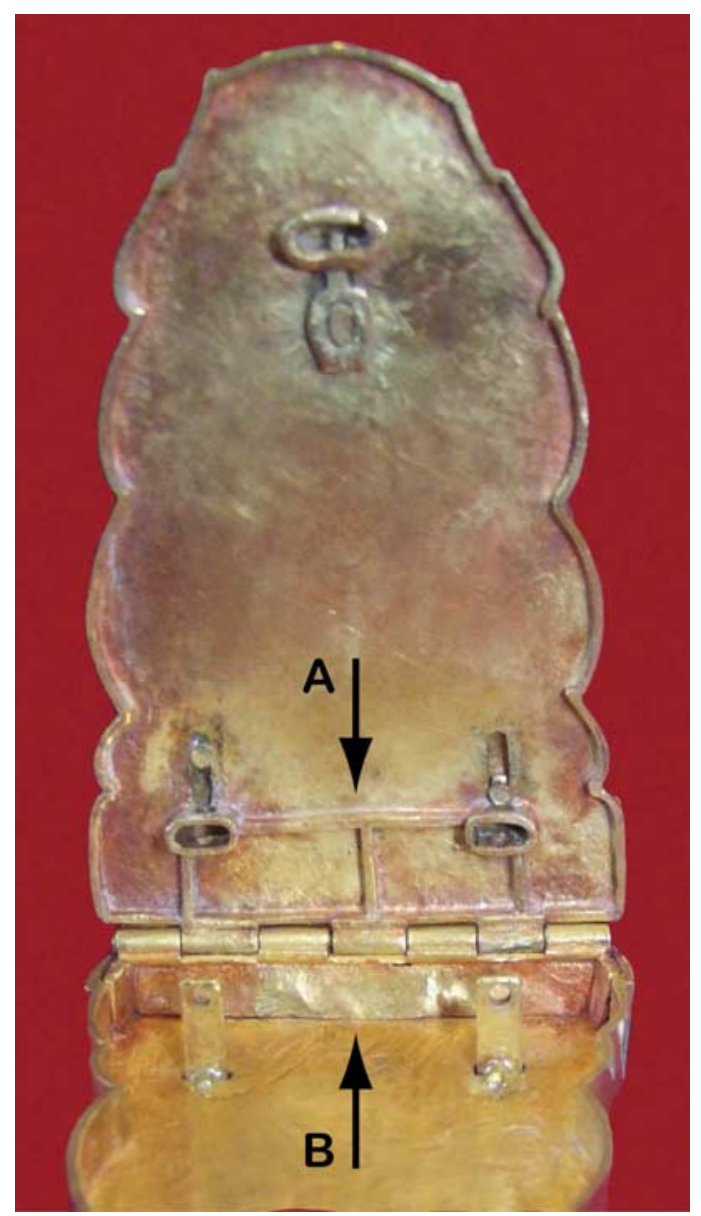

Fig 2. The back-plate of the great gold buckle from Sutton Hoo, Mound I, opened, showing the supposed 'reinforcement bars' (A) and the apparently added support bar for the hinge (B). Scale I:I. Photograph: author, courtesy of the Trustees of the British Museum

to display the price of the life of any nobleman in his hall or entourage, any cyninges geneat, as a dress-accessory on his belt - along, indeed, with many other spectacular pieces of the goldsmith's work: truly, then, an item of regalia.

This is, however, an appropriate point at which to re-open the question of whether the Sutton Hoo great gold buckle ever actually was worn on a belt. Despite the evident care in its construction, it has no means of attachment to a belt, and only a clumsy contrivance, that would leave the hinged parts half-open, can be suggested as a solution. ${ }^{58}$ On the face of the buckle, we find that the corners of the triangular back-plate adjacent to the loop are far more worn than any other part of the upper side, while the loop and tongue show no signs of wear at all (see fig I). This would be a natural consequence if, rather than being 
worn on a belt, the object were primarily a container in the form of a buckle with a hinged lid on the back-plate, which was repeatedly held face-down in the palm of a hand balanced on fingers touching those worn corners of the face and the lid opened to display what was inside. In those circumstances, then, the weight of the buckle would also be felt every time by whoever was holding it.

This author is not aware of any counterparts to the Sutton Hoo great gold buckle as a clear embodiment of a social value in this respect - except, of course, for the Crondall hoard of IOI tremisses, which it has been suggested was intended to represent the IOOscilling wergild of a freeman on the Kentish scale. ${ }^{59}$ The solid gold buckle in the recently discovered Prittlewell chamber grave, at $47.5 \mathrm{~g}$, has the weight of just over thirty-six tremisses of $\mathrm{I} .3 \mathrm{~g}$ and thus twelve solidi of $3.9 \mathrm{~g}$, but this is not a sum to which we can attach any distinct social meaning. We await precise figures on the weight of gold and silver respectively in the newly found Staffordshire hoard, but - noting that there is no information as yet on the fineness of the gold - the round figures currently given of $5 \mathrm{~kg}$ of gold and approximately I.3kg of silver are consistent with wergilds for some thirteen noblemen, and so between twenty-six and seventy-eight freemen, depending on the scale used for the lower, ceorl ranks of society. Such figures help us to appreciate - and indeed not to exaggerate - the contemporary value of this hoard. It is considerably less than the $19.5 \mathrm{~kg}$ of gold constituted by the 5,000 solidi inferrably paid in compensation for the death of Mul by Wihtred.

Even if correctly identified in the Laws of Æthelberht of Kent, a definitive exchange rate between gold and silver based upon a law embedded in the Theodosian Code need not have been introduced to England before that king's reign. The Gothic parallels to the terminology of sceatt and scilling, however, and perhaps also the weight of the Scandinavian eyrir, encourage the idea that a bimetallic system was observed in England earlier than this: indeed, may always have been a feature of Germanic culture in Britain. One aspect of the material culture of the sixth century, contemporary with most of the weighing sets discussed above, to which a relationship between and comparison of silver and gold is fundamental, is the emergence of the 'Bichrome Style' contrasting broad, plane silver fields with gilt relief zones on metal ornaments. This style was first defined by Hayo Vierck in the $1960:^{60}$ it is found in Kent, but achieved especial popularity in Anglian England by the mid-sixth century, becoming a defining feature of the dominant, numerously reproduced and highly standardized, great square-headed brooches of Groups XVI and XVII (fig 3). ${ }^{6 I}$ In light of the possible relationship with the eyrir, it is interesting to note that there are occasional counterparts in Scandinavia, too; ${ }^{62}$ although here, typically, rather than silver foil and mercury gilding being applied to a copper-alloy body, the body of the object is silver, with the relief areas parti-gilt. Rather than being merely decorative, this stylistic innovation may have been far more explicitly meaningful as an ostentation of wealth within a recognized system of values than has hitherto been appreciated.

If the propositions argued for in this paper prove valid, then, the reference points of economic value, at least in relation to major social transactions, were both carefully regulated and widely consistent from the very beginnings of Anglo-Saxon history. Such is,

59. Sutherland 1948.

60. Vierck 1965 and 1977.

6I. Hines I997, II8-4I, cf I42-5, I83-97 and 22I.

62. Ibid, 231. 

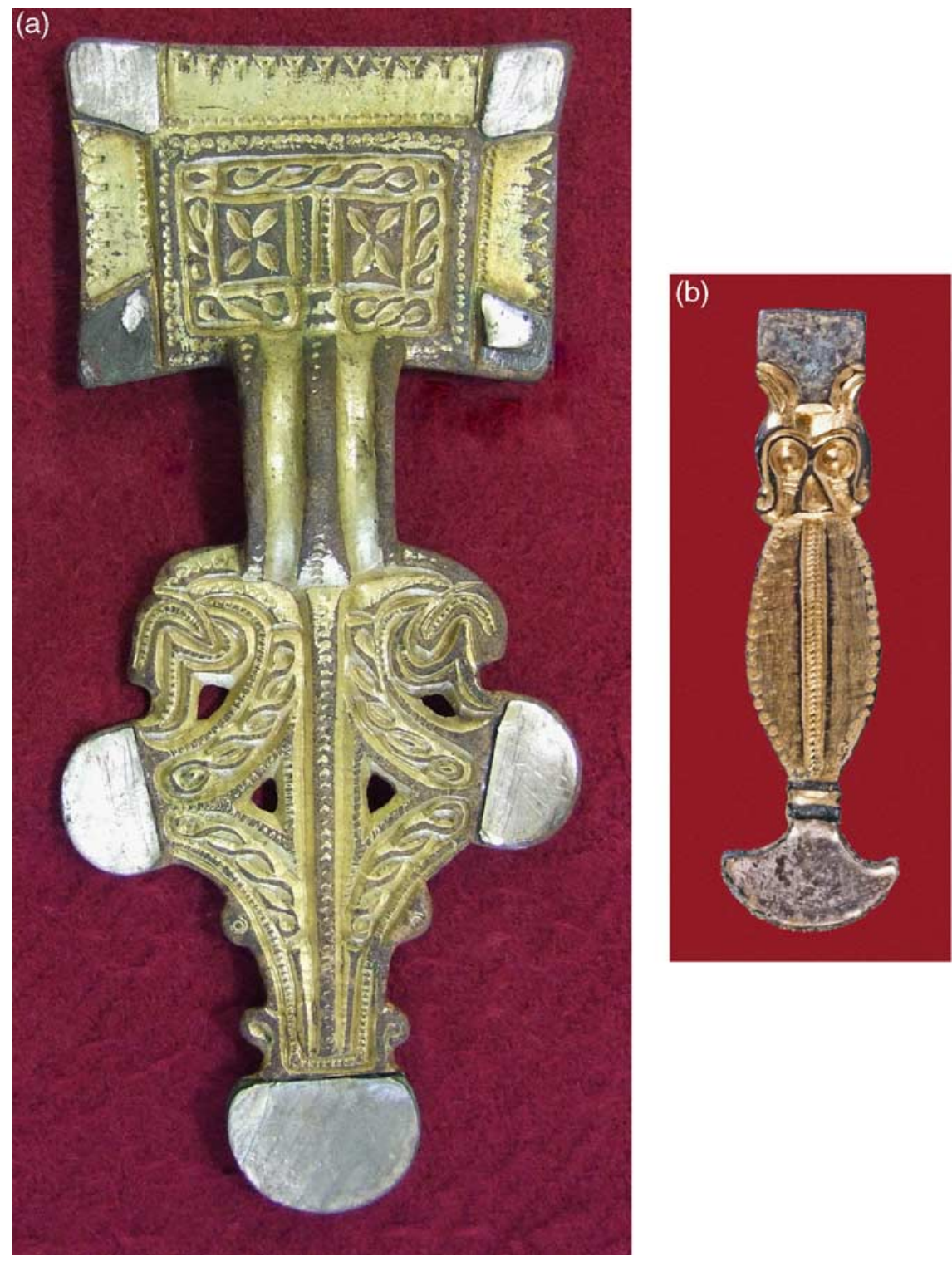

Fig 3. The Bichrome Style: (a) great square-headed brooch of the mid-sixth century from a woman's burial at Westgarth Gardens, Bury St Edmunds, grave 27; (b) pendant bridle-mount from an early sixth-century horse burial with a man at RAF Lakenheath, Eriswell, Suffolk. Scale I:I. Photographs: author

indeed, only to be expected with exchanges that are fundamentally socially embedded rather than enjoying some degree of freedom to respond to market conditions. ${ }^{63}$ In this light, it is noteworthy that Jos Bazelmans's analysis of Old English literature, especially

63. Grierson I959; Polanyi I97I, 3-25 and 139-74; Moreland 2000. 
Beowulf, in terms of social and economic anthropology, led him to emphasize both how gold and silver appeared to be the media that were inter-convertible with all other values and how the concept of personal 'worth' and the display of treasure were fundamentally conjoined. ${ }^{64}$ The more widely we may find this value-system to be encoded, though, the more urgent and influential we may infer that struggles for social and economic power none the less were, as the Germanic settlements gradually coalesced into Anglo-Saxon kingdoms.

\section{ACKNOWLEDGEMENTS}

The author's thanks to the organizers of research seminars at the Department of Coins and Medals of the British Museum, the Department of English Language, University of Glasgow, and in Medieval Economic History, University of Oxford, for opportunities to present and discuss the work and ideas embodied in this paper. Particular thanks too to Professor Christopher Scull, FSA, for reading a final draft and his supportive and helpful suggestions, of which full advantage has been taken.

\section{Manuscript sources}

\section{BIBLIOGRAPHY}

CCC $173(\mathrm{E})$

CCC 383 (B)

Textus Roffensis $(\mathrm{H})$
Corpus Christi College, Cambridge, Parker MS I73

Corpus Christi College, Cambridge, Parker Ms 383

Medway Archive, Strood, Kent

\section{Published sources}

Abdy, R and Williams, G 2006. 'A catalogue of hoards and single finds from the British Isles $c \mathrm{AD} 450-675^{\prime}$, in Cook and Williams (eds) 2006, I I-73

Attenborough, F L 1922. The Laws of the Earliest English Kings, Cambridge: Cambridge University Press

Bakka, E I978. 'Two aurar of gold: contributions to the weight history of the Migration Period', Antiq F, 58, 279-98

Bakka, E I98I. 'A set of weights from Late Roman or Early Migration times found at Bråten, Ringerike, eastern Norway', Frühmittelalterliche Stud, 15, 294-315

Bazelmans, J 1999. By Weapons Made Worthy: lords, retainers and their relationship in Beowulf, Amsterdam: Amsterdam University Press

Boddington, A I990. 'Models of burial, settlement and worship: the final phase, reviewed', in Anglo-Saxon Cemeteries: a reappraisal (ed E Southworth), I77-99, Stroud: Alan Sutton
Borethus, A (ed) I883-90. Capitularia regum Francorum, Monumenta Germaniae Historica, Legum Sectio II, 2 vols, Hanover: Hahn

Brøgger, A 1921. Ertog og Øre: Den Gamle Norske Vegt, Christiania [Oslo]: Vitenskapsselskapet

Bruce-Mitford, R L S 1975. The Sutton Hoo Ship-Burial. Vol I: Excavations, background, the ship, dating and inventory, London: British Museum Publications

Bruce-Mitford, R L S 1978. The Sutton Hoo Ship-Burial. Vol 2: Arms, armour and regalia, London: British Museum Publications

Burnett, A 1987. Coinage in the Roman World, London: Seaby

Campbell, A 1959. Old English Grammar, Oxford: Oxford University Press

Colgrave, B and Mynors, R A B (eds and trans) 1969. Bede's Ecclesiastical History of the English People, Oxford: Clarendon Press 
Cook, B and Williams, G (eds) 2006. Coinage and History in the North Sea World, Leiden: Brill

Fagerlie, J 1967. Late Roman and Byzantine Solidi Found in Sweden and Denmark, Numis Notes \& Monogr I57, New York: American Numismatic Society

Fell, C 1983. 'A friwif locbore revisited', AngloSaxon England, 13, I57-65

Geake, $\mathrm{H}$ 1997. The Use of Grave Goods in Conversion-Period England, c600-c 850, BAR Brit Ser 26I, Oxford: Archaeopress

Green, D H 1999. Language and History in the Early Germanic World, Cambridge: Cambridge University Press

Grierson, P I959. 'Commerce in the Dark Ages: a critique of the evidence', Trans Royal Historical Soc, 9, I23-40; reprinted in I979 in Dark Age Numismatics (P Grierson), no. II, London: Ashworth

Grierson, P I96I. 'La fonction sociale de la monnaie en Angleterre aux VIIe-VIIIe siècles', Moneta e scambi nell'alto medioevo, 34I-62; reprinted in 1979 in Dark Age Numismatics (P Grierson), no. XI, London: Ashworth

Grierson, P I991. Coins of Medieval Europe, London: Seaby

Grierson, P and Blackburn, M A S I986. Medieval European Coinages. Vol I: The early Middle Ages, Cambridge: Cambridge University Press

Harl, K W 1996. Coinage in the Roman Economy, $300 B C$ to $A D$ 70o, Baltimore: Johns Hopkins University Press

Hines, J I997. A New Corpus of Anglo-Saxon Great Square-Headed Brooches, Rep Res Comm Soc Antiq London 5I, Woodbridge: Boydell

Hughes, M J, Cowell, M R, Oddy, W A and Werner, A E A I978. 'Report on the analysis of the gold of the Sutton Hoo jewellery and some comparative material', in BruceMitford I978, 6I8-25

Jørgensen, L I994. 'The find material from the settlement of Gudme II: composition and interpretation', in Nielsen et al (eds) I994, 53-63

Jørgensen, L and Vang Petersen, P i998. Guld, Magt og Tro, Copenhagen: Nationalmuseet

Kent, J P C with Bruce-Mitford, R L S, Oddy, W A, Hughes, M J, Rigold, S E, Hill, P V, Fletcher, J M, Godwin, $\mathrm{H}$ and Burleigh, $\mathrm{R}$ I975. 'The coins and the date of burial', in Bruce-Mitford I975, 578-682

Kilger, C 2008. 'Wholeness and holiness: counting, weighing and valuing silver in the early Viking period', in Means of Exchange (ed D Skre), 253-325, Kaupang Excavation Project Pub Ser 2, Aarhus: Aarhus University Press

Krusch, B and Levison, W (eds) I95I. Gregorii Turonensis opera Teil I: Libri historiarum $X$, Scrip Rer Mer, I (I), Munich: Monumenta Germaniae Historica

Kyhlberg, O I986. 'Late Roman and Byzantine solidi: an archaeological analysis of coins and hoards', in Excavations at Helgö $X$ : coins, iron and gold (eds A Lundström and H Clarke), I3-I26, Stockholm: Kungl Vitterhets Historie och Antikvitets Akad

Leeds, E T 1936. Early Anglo-Saxon Art and Archaeology, Oxford: Clarendon Press

Lendinara, P I997. 'The Kentish Laws', in The Anglo-Saxons from the Migration Period to the Eighth Century: an ethnographic perspective (ed J Hines), 2 I I-43, Woodbridge: Boydell

Liebermann, F I903-I6. Die Gesetze der Angelsachsen, 3 vols, Halle: Niemeyer

Lyon, S I976. 'Some problems in interpreting Anglo-Saxon coinage', Anglo-Saxon England, 5, 173-224

Mattingly, H I960. Roman Coins, rev edn, London: Methuen

Metcalf, D M I993-4. Thrymsas and Sceattas in the Ashmolean Museum Oxford, 3 vols, London: Royal Numismatic Society

Mommsen, T and Meyer, P M (eds) I954. Theodosiani libri XVI: cum constitutionibus sirmondianis et leges novellae ad Theodosianum pertinentes, 3 vols, Berlin: Weidmann

Moreland, J 2000. 'Concepts of the early medieval economy', in The Long Eighth Century (eds I L Hansen and C Wickham), I-34, Leiden: Brill

Nau, E I97I. Epochen der Geldgeschichte, Stuttgart: Württemburgisches Landesmuseum

Nielsen, P O, Randsborg, $\mathrm{K}$ and Thrane, $\mathrm{H}$ (eds) 1994. The Archaeology of Gudme and Lundeborg, Copenhagen: Akademisk Forlag

Polanyi, K (ed G Dalton) I971. Primitive, Archaic and Modern Economies: essays by Karl Polanyi, Boston, Mass: Beacon Press

Rigold, S E I975. 'The Sutton Hoo coins in the light of the contemporary background of coinage in England', in Bruce-Mitford I975, 653-77

Scull, C I986. 'A sixth-century grave containing a balance and weights from Watchfield, Oxfordshire, England', Germania, 64, IO5-38

Scull, C I990. 'Scales and weights in early Anglo-Saxon England', Archaeol f, I47, I $83-2$ I5 
Snædal, M 1998. A Concordance to Biblical Gothic, Reykjavík: University of Iceland Press

Spratling, M 1980. 'The Sutton Hoo purse: analysing the weights of its contents', in Anglo-Saxon Cemeteries 1979: the fourth Anglo-Saxon symposium at Oxford (eds P Rahtz, T M Dickinson and L Watts), BAR Brit Ser 82, 363-70, Oxford: British Archaeological Reports

Steinmeyer, E and Sievers, E 1879-98. Die Althochdeutschen Glossen, 4 vols, Berlin: Weidmann

Steuer, H 1987. 'Gewichtsgeldwirtschaften im frühgeschichtlichen Europa', in Untersuchungen zu Handel und Verkehr der vorund frühgeschichtlichen Zeit in Mittel- und Nordeuropa 4: der Handel des frühen Mittelalters (ed K Düwel), 405-527, Göttingen: Vandenhoeck \& Ruprecht

Sutherland, C H V 1948. Anglo-Saxon Gold Coinage in the Light of the Crondall Hoard, London: Oxford University Press

Vang Petersen, P 1994. 'Excavations on Gudme-sites with treasure finds I984-9I', in Nielsen et al (eds) 1994, 30-40

Vierck, H E F I965. 'Some leading types of the Anglian province of culture, fifth to seventh centuries $\mathrm{AD}$, with their oversea connections' unpublished BLitt thesis, Oxford University

\section{RÉSUMÉ}

Au septième siècle, les lois locales des royaumes de Kent et de Wessex précisaient des amendes ou des dédommagements en unités de compte qui nous ont donnés des termes familiers de la numismatique de cette période: scillingas (shillings), sceattas et paningas (pennies). Au regard de l'emploi de termes apparentés en gothique et en vieux haut allemand, et des valeurs comparatives données dans les codes juridiques eux-mêmes en vieil anglais, et dans le Code Théodosien du cinquième siècle, on suggère que ces unités représentent un système bimétallique régulier et durable pour coordonner des valeurs en or et en argent. Cette proposition est examinée de plus près par rapport aux indices de séries de poids provenant de tombes anglo-saxonnes du sixième siècle et du début du septième siècle, et on soutient que les résultats donnent un sens plus important et plus précis à l'utilisation de l'or et de l'argent dans les objets fabriqués du début de l'époque anglo-saxonne, tels que la grande boucle en or du monticule I de Sutton Hoo, Suffolk.
Vierck, H E F 1977. 'Zur relativen und absoluten Chronologie der anglischen Grabfunde in England', in Archäologische Beiträge zur Chronologie der Völkerwanderungszeit (eds G Kossack and J Reichstein), 42-52, Bonn: Habelt

Voss, O I954. 'The Høstentorp silver hoard and its period: a study of a Danish find of scrap silver from about 500 AD', Acta Archaeologica, 25, I7I-2 I9

Webster, L 2000. 'Ideal and reality: versions of treasure in the early Anglo-Saxon world', in Treasure in the Medieval West (ed E M Tyler), 49-59, Woodbridge: York Medieval Press

Williams, G 2006. 'The circulation and function of coinage in Conversion-period England, $c$ AD 580-675', in Cook and Williams (eds) 2006, I45-92

Witthöft, H i984. Münzfuß, Kleingewichte, pondus Caroli und die Grundlegung des nordeuropäischen Mass- und Gewichtwesens in fränkischer Zeit, Ostfildern: Scripta Mercaturae Verlag

Wormald, P 1999. The Making of English Law: King Alfred to the twelfth century, Oxford: Blackwell

Wrede, F (ed) i9r3. Stamm-Heyne's Ulfilas, Paderborn: Ferdinand Schöning

Zupitza, J (ed) I880. Alfrics Grammatik und Glossar, Berlin: Weidmann

\section{ZUSAMMENFASSUNG}

Die aus dem siebten Jahrhundert stammende Volksrechte aus den Königreichen Kent und Wessex geben an, daß Geldstrafen und Entschädigungsgelder Betragseinheiten benutzen, die uns vertraute Benennungen aus der Numismatik dieser Periode abgeleitet haben: scillingas (Schillinge), sceattas und paningas (Pfennige). Angesichts des Gebrauchs von verwandten Wörtern im Gothischen und Althochdeutschen, und den vergleichenden Beträgen, die in den altenglischen Gesetzbüchern und in den Theodosischen Gesetzbüchern aus dem fünften Jahrhundert angegeben sind, wird gefolgert, daß diese Einheiten ein geregeltes und beständiges bimetallisches System darstellen, das auf Gold- und Silberwerten basiert. Diese Behauptung wird weiter im Zusammenhang mit Waagen und Gewichten untersucht, die in angelsächsischen Gräbern aus dem sechsen und frühen siebten Jahrhundert gefunden wurden. Es wird argumentiert, daß diese Schlußfolgerungen sibernen und goldenen Gegenständen aus frühen angelsächsischen Funden eine präziseren Sinn geben, wie zum Beispiel der großen goldenen Spange aus Grabhügel I im Fundort Sutton Hoo, Grafschaft Suffolk. 